\title{
Using the Abridged Version of some Novels as a way to Encourage Students' Written and Oral Production'
}

\section{Uso de versiones reducidas de algunas novelas como medio para fomentar la producción escrita y oral en estudiantes}

\author{
Gladis Leonor Arias Rodríguez \\ and Eliana Edith Roberto Flórez ${ }^{2 *}$ \\ Universidad Santo Tomás Seccional Tunja, Colombia
}

\begin{abstract}
This article analyzes the effect of working with the abridged version of some novels in order to promote students' communication in English. Two fourth semester English courses, from a private university, were randomly chosen to develop the different activities during one semester. The data was collected through students' written papers, the researchers' journal and a questionnaire. The findings show that students' constant work with this kind of literature, as well as the teachers' feedback, were factors that motivated their language use improvement; thus, they learned new expressions, did written and oral training, and acquired knowledge thanks to the contact with other cultures through literature.
\end{abstract}

Key words: action research, abridged novels, listening exercise, written and oral practice

\section{Resumen}

Este artículo analiza los efectos de trabajar con la versión corta de algunas novelas con el fin de promover las habilidades escritas y orales de los estudiantes. Dos cursos de inglés de cuarto semestre, de la Universidad Santo Tomás

1 Received: July 27th 2017/Accepted: April 19th 2018

2 gladis.arias01@usantoto.edu.co; eliana.roberto@usantoto.edu.co 
Tunja (USTA Tunja), fueron escogidos al azar para desarrollar las diferentes actividades durante un semestre. Los datos fueron recolectados a través de las composiciones escritas de los estudiantes, el diario de las investigadoras y una encuesta. Los resultados muestran que el trabajo constante de los estudiantes con este tipo de literatura, así como la retroalimentación de las profesoras, motivó el mejoramiento del uso de la lengua; de esta manera, ellos aprendieron nuevas expresiones, hicieron ejercicios orales y escritos, y adquirieron conocimiento gracias al contacto con otras culturas a través de la literatura.

Palabras clave: investigación-acción, novelas abreviadas, ejercicio de escucha, producción escrita y oral.

\section{Resumo}

Este artigo analisa os efeitos de trabalhar com a versão curta de algumas novelas com o fim de promover as habilidades escritas e orais dos estudantes. Dois cursos de inglês de quarto semestre, da Universidade particular em Tunja, foram escolhidos por acaso para desenvolver as diferentes atividades durante um semestre. Os dados foram coletados através das composições escritas dos estudantes, o diário das pesquisadoras e uma enquete. Os resultados mostram que o trabalho constante dos estudantes com este tipo de literatura, bem como a retroalimentação das professoras, motivou o aprimoramento do uso da língua; desta maneira, eles aprenderam novas expressões, fizeram exercícios orais e escritos, e adquiriram conhecimento graças ao contato com outras culturas através da literatura.

Palavras chave: pesquisa-ação, novelas abreviadas, exercício de escuta, produção escrita e oral. 


\section{Introduction}

7 his article aims to share the results of some research procedures under the collaborative action research as a way to describe the effects of working with the abridged version of some novels with listening support to encourage students' written and oral production in fourth semester at a private university in Tunja, Colombia. It was developed during the second semester 2016.

There are many activities teachers develop in the classrooms, but they are not always enough to motivate students' language acquisition. Thus, during this study, it was necessary to change the traditional class material (the textbook) and the syllabus in order to develop a pedagogical intervention based on the abridged version of some novels. It permitted teachers to use different activities, materials and strategies which had a great impact on students because learning became an amazing task for them.

This study was conducted based on a pedagogical intervention in which teachers and students interacted in order to generate some changes in the dynamics of the class; thus, students could be exposed to the language use through listening, writing and speaking, activities that permitted students to practice language and improve their capacity for communicating their ideas with fluency and accuracy.

\section{Statement of the problem}

The interest behind developing this research was born when the researchers verified that despite their constant work guiding students in the acquisition of the English language with the use of textbooks, they presented deficiencies when communicating ideas in different contexts. For example, after reading short texts in the class, the teachers asked students to speak about their understanding of things like general ideas or specific details of the text, but only few students used to answer; before starting a new topic, the teachers usually do some brainstorming or ask a few questions about the pictures, titles or subtitles of the book; again, only few students used to participate. It made the researchers think that the students' English lack of enough language tools to participate and express their ideas.

In order to verify these perceptions, the researchers developed a diagnostic procedure based on the abridged version of the novel; accordingly, students listened to the first chapter of the abridged version of the novel: "The Phantom of The Opera", after that, students had to 
write a paragraph with their own words about the main idea and share it with the class orally; this is one the samples:

Cristina the girl sing the opera. A monster in the dark. Girl beautiful sing.

Raul is the friend. He is a friend child but Cristina not recognize Raul.

A monster, a man strange in the corridor.

The girls see the ghost. The girls afraid. (students' written composition)

Analysis of the previous excerpt: the student wrote a very short composition, it evidences his poor understanding and lack of vocabulary to express his ideas, it contains some mistakes in coherence and syntax; additionally, in the speaking activity, which was done after the paper composition, only two students participated, their interventions were very short and not clear enough to understand their message, some of them said they did not know how to express their understanding of the novel and just stayed silent. Considering this diagnostic exercise which evidenced students' problems to communicate, the following main research question was proposed: What are the effects of working with the abridged version of some novels with listening support in order to encourage students' written and oral production in fourth semester at a private university in Tunja?

\section{Theoretical Framework}

\section{Teaching English through the abridged version of novels}

The implementation of novels for teaching have been regularly used for teaching English due to the benefits they present, Hişmanoğlu (2005) said, "The use of a novel is a beneficial technique for mastering not only linguistic system but also life in relation to the target language". (p. 63); nevertheless, due to their length, it is not easy to read this kind of material in class. The use of abridged versions of novels is an option teachers have to motivate the acquisition of the target language because they can be adjusted to the conditions of the class, for example the students' likes or their English level.

These kinds of novels are totally accessible in the teaching context due to the characteristics they have: there is a great variety of topics (adventure, love, comedy, fiction, among others); Beach, Appleman, Hynds \& Wildhelm (2006) state that it is important to select topics students have some familiarity or interest with, or that may engage 
them. Additionally, the abridged versions of novels with listening support are usually classified according to the students' age and level of language, (Common European Framework of Reference for Languages (2001): elementary, intermediate and advanced levels), publishers offer a wide variety of them which teachers can choose from, based on the students' interests or the purpose of the class.

Additionally, the listening support is a factor that contributes to make the act of reading more multi-faceted and serves as a language model with regards to pronunciation, intonation, fluency and comprehension. Chen (2014) argues that listening provides a positive experience using the target language; it helps students develop vocabulary and understanding of literary issues. Besides, the use of the abridged versions of some novels is an important literary resource to teach in class; some authors think that this material conserves the characteristics of the original versions, they have the same benefits of the original books full versions; moreover, Yeo (1986) asserts: "People who abridge stories assume that the plot is the most important aspect of a classic. A classic, to them, is essentially a classic story and this they want to convey, albeit in its reduced form, to school students". (p. 23). Hişmanoğlu (2005) states: "Using novels makes the students' reading lesson motivating interesting and entertaining" (p. 64). In fact, this kind of material is both enjoyable and understandable for students; it enhances students' habit for reading and increases their speaking skills.

While listening to the abridged versions of novels students can develop their listening skills, which are necessary as an input in order to develop the other three skills (reading, writing and speaking). Renukadevi (2014) argues: “... listening contributes primarily for language expertise. Listening awakens awareness of the language, as it is a receptive skill that first develops in a human being. Learning to listen to the target language improves language ability" (p. 59). The previous statements show how necessary it is to include materials that involve listening activities in language acquisition.

One of the most important benefits of using literature for teaching English is the great amount of communicative and interactive activities that can be done in the classroom; thus, students gain in practice and surpass their difficulties in the process of acquiring the language; Koutsompou (2015) argues: "The purpose of using literature in a language classroom is to make the class interactive and it can be stated that an interactive class can obviously improve communicative competence of the learners and keep a lasting impact on their mind" (p. 75). In addition to the contributions of literature for teaching, the 
listening support of the books calls students' attention because they can listen to the characters and make a mental picture about the situation which is a factor that motivates students learning and understanding.

As a cultural aspect, literature offers teachers and students the possibility to acquire knowledge about human customs and evolution including social advances and problems, about it, Koutsompou (2015) states "Through literature students get to know the background not only of the particular novel but also, they learn about history, society, and politics of the country described in the novel or story" (p. 75). Knowledge acquisition and language learning are two purposes coherent with the education in teaching a foreign language; hence, this is complete material that cultivates students' feelings and perception of the life in different contexts.

Literature, represented in abridged novels, makes a very significant contribution towards the exposure of students to language patterns in real life situations, more than an academic language; Koutsompou (2015) argues "The linguistic criterion defends that literature should be used in language teaching, because it provides the learner with genuine, authentic samples of language, and with real samples of a wide range of styles, text types and registers" (p. 75). This is what some authors consider as authentic language because it is written not with the purposes of teaching but with the objective to tell a story, to evidence the situation of real life or fiction; Berardo (2006) asserts: "One of the main ideas of using authentic materials in the classroom is to "expose" the learner to as much real language as possible. Even if the classroom is not a "real-life" situation, authentic materials do have a very important place within it. (p. 64); consequently, language teachers are required by the education system to propose strategies that approach students to acquire the language in real contexts that really prepare students for real life situations.

Having in mind that listening is one of the first skills man develops to learn a language, the improvement of this ability helps students to comprehend different situations and it is also a base to interact with the context, Renukadevi (2014) notes that when learning a language with a communicative purpose, listening plays a vital role, as it helps the language learner to acquire pronunciation, word stress, vocabulary, and syntax. Thus, the abridged version of novels with listening support helps students to have the opportunity of learning how the comprehension of a message is carried with elements like the tone of voice or the pitch or accent. 


\section{Speaking and writing skills development and literature}

Speaking and writing are the main skills students have to develop in order to communicate their ideas, feelings, explain their view points, argue, discuss among others; hence, this is very important to motivate them from the classroom. Ritlyavá (2014) asserts: "The reason for learning the language is to be able to use it in practice, to make oneself understood. Thus, the most frequent way of using it is speaking" ( $p$. 99). Likewise; writing is also a way to share ideas, it can be formal or informal, it depends of the purpose of the writer, and both can be developed in the classroom.

Literature is a very wide field that can be linked to speaking and writing as an input to develop these skills, after listening or reading a novel, students are able to communicate their understanding through them. Tehan, Yuksel and Inan (2015) highlight the use of literature in the classroom due to its academic, linguistic and cultural importance and because it encourages students to talk about their opinions and stimulates language acquisition. In fact, it is necessary to give students opportunities to use the foreign language in the classroom or outside in order to practice and acquire it, accompanied by the teachers' feedback as a support to improve the appropriate language use according to the situation.

Additionally, authors like Sell, Rogers, Harmer, and others, in Tamo (2009) think that literature is an authentic material to be used in the classroom due to the advantages it has in terms of language acquisition and language use. Besides, literature is considered authentic material because it is not written for academic purposes as well as the newspapers, magazines, poems, among others, but it can be used as a teaching resource.

Bringing authentic materials into the classroom can be motivating for the students, as it adds a real-life element to the student's learning experience. Authentic materials are significant since it increases students' motivation for learning, makes the learner be exposed to the "real" language" (Tamo, 2009, p. 75)

In the same way, some English teachers have developed research procedures around the implementation of literature in the English classes, about it, Giuria (2015) reports "Even though the four participants have different views on literature, they all recognize three main reasons for teaching it in the English classroom: to improve the language, to gain knowledge and understanding of other cultures and to grow as a person" (p. 28). Thus, the previous arguments show the 
utility of literature in the English classes and the variety of approaches teachers can do with this material.

Likewise, literature can support the speaking and writing skills taking into account that they require much effort for students and teachers because they evidence the students' learning and real use of the language; hence, literature as an authentic material and accessible source teachers must work in the classroom, stimulates students' communication with activities like: describing places, retelling chapters, criticizing the topics, discussing about social problems, doing role plays, describing the characters' roles, analyzing social problems, economic situation, among others.

Moreover, a way to guarantee students' learning English is by promoting those activities that include students' production due to the fact that they motivate their thinking and communication, Elftorp, (2007) states, "The purpose of everything you do in English classes is to help students to develop their writing and speaking skills, regardless of whether it is grammar, drama or national tests" (p. 5); besides Phat (2013) declares, "I hold a strong belief that literature would be a great potential resource in teaching language and communications skills, especially speaking skills for the language learners." (p. 673); thus, the importance of these skills lies on the need people have to share their feelings, life perceptions, knowledge, events, among others; in this case, literature is favorable to promote students' language learning.

Additionally, culture is an inherent aspect to literature and the English class; it approaches students to the real discourse, social conventions and reflexive issues; thus, literature can be seen as a bridge between students and the real life, full of meaning through the society and their history. Riwes (2010) remarks: "In the end, the role of culture in ELT is crucial, since it will mean the difference between casual speakers who remain outsiders and speakers who understand the meaning behind the words and the world that is constructed by them" (p. 8). In this way, teachers' role is to guide students build their own reflection based on the experience, motivating their critical thinking, focusing students to contrast cultures and learn about the experience of foreign cultures.

The aspects above are reasons and strengths for including the abridged versions of novels in English classes; they contribute to support how meaningful this material is. It only requires teachers to take the risk and change the traditional classes where students just sit down and listen to the teacher; this is a possibility not only to promote students' learning about different topics but also to empower their communicative skills based in real material. 


\section{The use of feedback in language learning}

Feedback is a common strategy English teachers use to guide students to correct their performance, it can be done individually or in group according to the needs, it allows teachers to understand students' difficulties and strengths in order to follow a process and look for strategies that facilitate learning, according to the individual capacities. Here are some recommendations:

Break down the instructions by using simple sentences so that the students can easily understand, use demonstration whenever possible, not to over correct the errors, avoid giving negative feedback to increase student's self-motivation, provide sufficient independent practice to overcome their errors and re-teach the material when necessary. (Akhter, 2007, p. 10)

The suggestions above evidence the teachers' real role in teaching a foreign language; hence, it is imperative that teachers create an appropriate environment to guide students, for example face to face feedback in a tutoring session close to the class; according to the Department of Education and Communities (2015): "Feedback during learning allows students to take feedback on board immediately and to try to realize improvement during the learning process" (p.1); In fact, the feedback is not a formal activity but a very useful tool to support students in their learning process; during writing, students usually require the teacher's feedback in order to use the appropriate word order, conjugation, connectors or the adequate tense according to the context; during speaking, students usually require feedback in pronunciation and also in the coherence of their ideas with the purpose to express what they really want to say.

During learning another language, it is necessary to create an environment of self-confidence where the students can express their doubts in a spontaneous way, and the teacher can clarify them in the best way. Hattie and Timperley (2007) maintain that an ideal learning environment occurs when both, teacher and student work together to overcome learning difficulties. Besides, Carvajal and Roberto (2014) point out that the constant dialogue and feedback facilitate the work atmosphere without being concerned about mistakes. Thereby, feedback has a positive effect when it impacts the students' behavior and when it helps students to identify their own strengths and weaknesses in terms of learning; thus, they are able to take their own decisions to surpass their difficulties. 


\section{Methodology}

This study used the qualitative approach through the collaborative action research as the method to improve some specific conditions of a group of students because it permits to do changes based on evidences, monitor, refine and adapt new conditions in order to get positive results. Many researchers in education use this method due to its benefits in terms of learning and improvement. Alba (2015) states about the Collaborative Action Research: "CAR is used worldwide as an effective means of lifting the burden of improvement from the shoulders of unsupported individual teachers and enabling them to tap into the collective knowledge and experience of a broader group of practitioners" (p.3). In fact, one of the advantages of this method is the great opportunity for students and teachers to work together in the same learning purposes; besides, Alba (2015) highlights that CAR contributes to: "improving students learning, improving individual professional practice, wider professional development and comparing professional isolation" (p. 3); thus, this is why this method permits to evidence the results in short time, and also joins theory and practice in order to improve results during academic procedures.

\section{Setting and Participants}

This study took place at a private university in Tunja Colombia, where there are different programs such as engineering, public accounting, business administration, law, and architecture; students take five mandatory basic English courses: additionally, they come from different municipalities of Boyacá; the students who were involved in this research were about 18 and 19 years old; according to some exams applied by the university, students were between A1 and A2 according to the common European Framework (2011) which are lower than the expected, which was $\mathrm{B} 1$.

This study was conducted with a group of thirty-two fourth semester students, and data was collected from fifteen of them who were chosen at random. Two teacher trainers were responsible for planning, implementing and assessing the different activities. 


\section{Data Collection Instruments and Data analysis}

Data was collected through a questionnaire, students' artifacts and the researchers' diaries:

Questionnaire, it was administered to students at the end of the workshops. According to Abawi (2013), this technique allows the researchers to collect the most complete and accurate data in a logical way. Thus, this instrument enabled researchers to evidence and examine students' work, as well as their personal perceptions about the development of the project.

The artifacts are represented in this study in the students' written and oral production which were the output activities. McGreal, Broderick, and Jones (1984) propose the use of artifacts for teaching in order to facilitate students' learning; thus, these allowed the researchers to identify students' difficulties, mistakes, language improvements, the learning process and they also facilitated the feedback work.

Diaries, these were carried out by researchers during the development of all the different activities; about it, Iida, Shout, Laurenceau, and Bolger (2012) assert: "Diary methods involve intensive, repeated self-reports that aim to capture events, reflections, moods, pains, or interactions near the time they occur" (p. 227). Hence, this instrument allowed the researchers to register the most important moments of the class and kept evidences of all their observations, thoughts and reflections about the English classes as well as the students' performance, reactions and difficulties during the class development.

Data analysis was conducted throughout the grounded theory approach because it provided procedures for analyzing collected data through different instruments. Charmaz (2006) states that grounded theory helps to direct manage and streamline data in order to construct the analysis. Moreover, Glaser and Strauss (2006) argue that grounded theory allows the researchers to move from data and theory with the purpose to create new theories in a specific context. Thus, after collecting data, a coding process was carried with the purpose to look for emerging patterns, issues and ideas; some preliminary categories were formulated; after that, questions, theory and categories were reread; based on the previous exercises, two main categories were established, they involved the most relevant and repetitive information taken from data.

Additionally, triangulation was done in order to validate findings; Yeasmin and Rahman (2012) state: "Triangulation is a process of verification that increases validity by incorporating several viewpoints 
and methods" (p. 156). After collecting, grouping, comparing, coding, labeling data, and establishing categories, the triangulation procedures were implemented with the purpose to analyze, argue, confront and theorize data; thus, new theory emerged in favor to the teaching and learning procedures, by using the abridged version of some novels in the English classes.

\section{Instructional design}

For the development of this study, the following procedures were carried out:

First step: the researchers planned the project and collected the material: four abridged version of short novels (Great Expectations, Frankenstein, The Prisoner of Zenda and Oliver Twist), with listening support.

Second step: the researchers elaborated four workshops, one for each novel, they contained different strategies: pre-listening activities, while listening, post-listening activities and oral exercise, as explained in Table 1.

Third step: the researchers shared the current project with the students and started its implementation and data collection; it was done with the purpose to communicate them about the different activities that were going to be developed in those specific English courses.

This study followed Buck's (2001) suggestions in relation to pre-listening, while-listening and post-listening activities which are common classroom exercises in language acquisition, each one depends on the teachers' focus, the students' interests and the objectives of the class; thus, these workshops were focused to listen to the abridged version of four novels in order to encourage students' written and oral production. 
Table 1. Workshop development

\begin{tabular}{|l|}
\hline \hline \multicolumn{1}{|c|}{ First workshop } \\
\hline Novel: "Great Expectations" \\
Pre-listening activities: Students looked at and analyzed pictures of \\
the novel to predict the content. \\
While listening: students listened to the book; next, researchers and \\
students did a brainstorming about the general understanding of \\
the novel.
\end{tabular}

Post-listening activities: the students were divided up according to the number of chapters (13); each group checked a specific chapter and produced a written summary.

Language function: summarizing with the students' own words, using appropriate verbal tenses and connectors as needed.

Oral exercise: students prepared an oral presentation about their understanding of each chapter, based on their own summary.

\begin{tabular}{|l} 
Second workshop \\
\hline Novel: "Frankenstein" 4 \\
Pre-listening activities. the researchers asked students some
\end{tabular}

Pre-listening activities: the researchers asked students some questions about the novel to get them familiar with the content.

While listening: students listened to the novel, after that, they exchanged ideas about it.

Post-listening activities: in small groups, students chose a specific character of the novel and produced a written description about them including features, values, weaknesses, strengths, physical and emotional description and his/her role in the novel.

Language function: Describing characters by using the appropriate adjectives and verbal tenses according to the context of the novel.

Oral exercise: students talked about the different characters based on their own papers, with the aid of pictures.

Third workshop

Novel: "The Prisoner of Zenda"s

Pre-reading activity: Students analyzed the heading and the title of the different chapters to infer what the book was about.

3 Dickens, Ch., adapted by Evans, V. \& Dooley, J. (2002). Great Expectations USA: Express Publishing.

4 Shelley, M., adapted by H, Q. Mitchell (1994). USA: mm publications.

5 Hope, A., adapted by Evans, V. \& Dooley, J. (2002). The Prisoner of Zenda. USA: Express Publishing 
While listening: students listened to the novel, subsequently, some of them talked about their general perceptions of the novel.

Post-listening activities: in small groups, students chose a specific scene from the novel, then, they did an exhaustive written description about it.

Language function: Describing specific events, use of appropriate time expressions, verbal tenses and adjectives.

Oral exercise: students explained the different scenes in oral way.

Novel: "Oliver Twist",

Pre-reading activity: students looked at the pictures to predict the content of the novel.

While listening: students listened to the novel, except the last chapter. Then, the researchers asked students about their general understanding of the novel.

Post-listening activities: in small groups, students wrote an alternative ending to the novel.

Language function: use of appropriate time expressions, verbal tenses, connectors, adverbs and adjectives as needed.

Oral exercise: students presented an oral presentation on their ending with the aid of pictures.

6 Dickens. Ch., adapted by Evans, V. \& Dooley, J. (2002). Oliver Twist. USA: Express Publishing. 


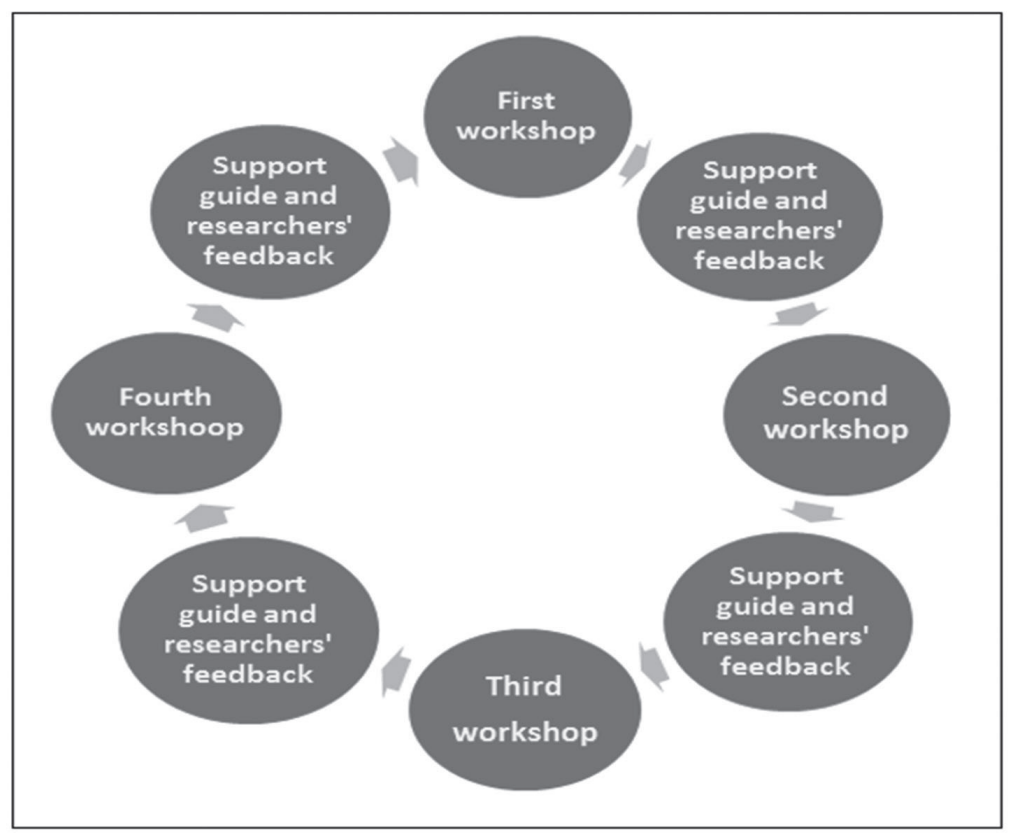

Figure 1. Collaborative action research cycles

Additionally, the researchers did constant corrections throughout the different stages of the investigation in order to correct grammar mistakes, punctuation, coherence, and pronunciation. After the development of each workshop, the researchers met and analyzed students' performance (difficulties, progress and needs), thus they planed additional guides (about the use of conjugation, punctuation, adjectives and connectors) in order to support and improve students' written and oral production. During all the activities, students worked in groups of two or three. When carrying out oral presentations, students used pictures, posters and graphic organizers as aids.

\section{Findings}

According to data collection analysis, and focused to answer the research questions, there are some findings that evidence advantages, improvements and difficulties while working with literature material; first, listening to the abridged version of some novels was a factor 
that motivated students' written and oral production in the English classroom; second, there are inherent aspects that literature presents to students such as knowledge acquisition, cultural enrichment and personal interest for literature topics; these topics are represented in two main categories as follows:

\section{First category: students' writing and oral development through listening to the abridged version of some novels}

This category evidences how the exposure students had to the abridged version of short novels, with listening support, enhanced their written and oral production. First, during the listening sessions, the voice and the intonation of characters, as well as the plot were aspects that motivated students to be involved in the activities. However, in the first novel, students had some difficulties understanding the complete development of events, especially because they did not use to work with this kind of material and they did not understand some new vocabulary, the pronunciation of some phrases as well as the speed at which the students had to listen. Some students said:

I had problems with the vocabulary in the listening work, because the characters did not speak slowly and it was difficult for me to understand. (Questionnaire, question 3, student 7)

Considering that students had some difficulties to fully understand the content of the novel before the written and oral production, the researchers organized the students by couples in order to check the novel again, then, they proceeded to write their own summary and prepare their oral report. At this stage, the researchers' support for making feedback in the corrections of the papers and in the oral preparation, especially in pronunciation corrections, was very important to accomplish with the first workshop. Su \& Tian (2016) state "In second language learning and teaching, feedback refers to any commentary information to learners' performance" (p. 440). Thus, accompanied by the feedback, the support guides helped students to correct and improve their written or oral problems along the different activities. About it, one of the researchers argued:

"There were some difficulties to start motivating students' written and oral production, especially at the beginning; they required explanations about aspects like conjugation, use of appropriate connectors, and others, to produce paragraphs on only single sentences; and in the pronunciation of some phrases." (Researcher 2 , diary) 
Moreover, about the $4^{\text {th }}$ question, "What difficulties did you have during your oral and written production?", one of the students answered:

"My principal problem is the use of connectors, I don't know what is the appropriate according to the context, I have also some difficulties in speaking with fluency, and sometimes I forget the words I need to communicate my ideas." (Questionnaire, question 4, student 5)

In fact, during the development of the different workshops, the students' written production evidenced the existence of some difficulties in the use of the appropriate conjugation according to the context, word order, connectors, and others; in that moment, the researchers implemented strategies to help students improving their language mistakes, the most important was the constant feedback (individually and in group), and the application of the supported guides, as explained in the instructional design. In studies done by Vasu, Hui Lin \& Nimehchisalem (2016), they report that most of the students prefer teachers' written feedback because it helps them a lot to improve their performance in writing and through time students become autonomous according to their own capacities to interiorize the language. As a matter of fact, this research project evidences that an effective written feedback helps students build the necessary language tools to improve their communication not only in written way but also in the oral performance along time.

The abridged version of some novels with listening support as well as the written activities developed along this research focused students to engage and improve their oral production. Thus, the students' written production was the previous step students did before their oral performance; they also used their papers as the base to present their oral reports. Previously the final oral report, students carried out some oral training to get fluency, improve pronunciation, correct pronunciation and prepare the final oral presentation; this activity was supervised by the researchers in order to give students feedback when necessary.

During the oral presentations, students passed by a process of constant progress; the work they developed in each workshop contributed with the students' self-improvement. About it, one of the researchers argued:

"Some students show more difficulties that other during their oral presentations basically in pronunciation and fluency, but it is perceived that most of them try to do their best, there is certain competition among them because they have to expose their own 
production in front of the group, during their presentations they prepare pictures and power point presentations to have some visual aids during their oral performance." (Researcher 2, diary)

Likewise, about their English oral performance during the classwork, one of the students asserts:

"For me, the most difficult is to speak with fluency, I feel I need more vocabulary and practice; I think that the work we have done this semester, studying with novels not with textbooks as usually, has been a good idea for helping me to practice my English, I have had the opportunity to write and speak a lot. It is not easy for me, but it is a good exercise to improve my English." (Questionnaire, student 4)

The English oral practice in the classroom is very important for students because they learn how to use the langue in real situations; in this research, literature was a great source for guiding different activities in order to motivate students' speaking. Hişmanoğlu (2015) declares that literature develops oral and written skills, it helps students understand the English linguistic system, and the students also can acquire idiomatic expressions that help them speak clearly; thus, the use of the abridged version of novels motivate students oral practice due to their wide variety of topics and activities teachers can develop in the classroom.

Subsequently, the constant listening, oral and written training, accompanied by the researchers' feedback as well as the support guides, contributed to improve students' communication. It was demonstrated in the latest reports students presented, thus, one of the groups wrote their own version for the end of Oliver Twist:

When Oliver Twist went to live with Mr. Brownlow, he started to study philosophy because he loved reading. He lived so happy with his new family and helped MR. Brownlow with the library. When he finished the university, he married a beautiful girl he met at the university, they had three children and created an institution to help children in need, it as was his best satisfaction with the life and he lived happy for ever. (Fourth workshop, group 2, students' written artifact)

The previous excerpt evidences the students' improvement in comparison to the first papers; besides, while students improved their written compositions, their oral production was better too. To have these results, students and researchers had to work so hard in doing the corrections and practicing the oral presentations, as it was confirmed by 
the researchers' observations in their diary:

Students written and oral corrections was a tiring work, but the enthusiasm they showed in the moment to present their oral reports and their concern to do their best, was really a good experience. (Researcher 1, journal)

I think that it was not easy for students because they worked very hard, they had to understand the novels, when they did not, they asked their partners or the researchers about it. In the compositions, they had to include new expressions and vocabulary, take care with conjugation, be coherent, use connectors, among others; additionally, when speaking, they had to express their oral report in the way that the researchers and their partners understood them in the best way. It was a challenge for them. (Researcher 2, journal)

Likewise, some students stated they did not have much difficulty with the comprehension, they enjoyed the novels, took advantage of the different workshops and improved their written and oral production thanks to the emphasis the workshops had for developing these skills. About, a student argued:

I believe that these types of activities should be implemented for teaching English because we learn vocabulary, pronunciation, grammar, and it takes away the fear of speaking. (Questionnaire, question 7)

Finally, the students' opinions, their written and oral performance as well as well as the researchers' views about the development of the different workshops, evidence the advantages of using literature in the English classes to enhance students' written and oral communication. Additionally, the researchers' support through the feedback helped students improve their language use and promoted students' selfconfidence to overcome their difficulties in terms of language acquisition.

Second category: students' involvement in knowledge acquisition and cultural enrichment

The development of different workshops based on the abridged version of some novels, permitted students to be involved in particular aspects inherent to people's life and development such as knowledge acquisition and cultural aspects. In fact, the classic books of literature (Great Expectations, Frankenstein, The Prisoner of Zenda and Oliver 
Twist) selected for this research project give testimony of specific moments in the history of towns, about people customs, social problems, among others; additionally, they include the fantasy and fun of literature which make them enjoyable and interesting for students.

Likewise, one of the characteristics of literature is to evidence people's customs and history; for example one of the novels students listened to was "The prisoner of Zenda", it took place in a central European Country named Ruritania, during the kingdom of Queen Victoria (1837-1901), it was a story of love and honor that implicated students in learning about relevant aspects of people from that age, such as the conflicts of a real family who had to live the desire of power and government and also the emergence of the industrial revolution which was a very important moment in the history of humanity; thus, as students declared about it:

I learned more about the life of people in Europe, the most interesting was the rise of the industrial revolution, when people began to build the great railroads, and the development it produced in the society of that age. (Questionnaire, student 6)

Literature, seen as a cultural manifestation, is full of meaningful contexts, during working with this material, students experimented the contact with other cultures, and they could perceive people's traditions, for example in the novel Great Expectations students were immersed in the English society of the nineteenth century, when reality and fiction was not clear enough, people believed in the changes of the weather as signs of good or bad luck, the perceptions of guilty and innocent were manipulated for people according to their personal interests or their social class convenience. About it, one of the teachers wrote in the journal:

During the development of the first workshop, students could be immersed in a different culture and environment; they analyzed English people's customs, their problems, needs and feeling. (Researcher 1, journal)

Moreover, with the Frankenstein novel, students felt passion for the class work, its component of fiction, the perspective of science and technology of the nineteenth century as well as the adventures of the leading role (Víctor) made students feel passion for literature. Cornillon (2016) argues about this novel: "The work raises questions on the limits of science and the dangers facing humans who want to unravel the mystery of nature" (p. 2), in fact, this book has been one of the classics of literature, it has been translated to different languages and taken to the cinema; in the same way, Hişmanoğlu (2005) affirms, 
"In novel, characters reflect what people really perform in daily lives. Novels not only portray but also enlighten human lives". (p.63); thus, it is important that students reach this material as part of their academic life; as one of them argued:

It was a great experience, different to the way we have been working in English. Listening to these novels was pleasant and, at the same time, I learned a lot about people's lives in other countries for example about the industrial revolution, people's customs, their difficulties, problems, conflicts, and others. (Questionnaire, student 11)

Furthermore, literature also has the property to sensitize people; novels like Oliver Twist, written in 1838, shows the vulnerability of children, it recreates the situation of an orphan from an unknown town in England, but it really reveals the situation of many children who live in many cities and countries around the world, thus, this research evidenced how students were also critical in front of children's violation of their human rights; besides, when students developed the fourth workshop and wrote the end of this novel, they could express their own thinking and the way to solve real-life problems as follows:

After overcoming a lot of problems in Fagin's house, Oliver became a great leader with the help of Mr. Brownlow, the man who adopted him. As he had had a childhood full of necessities, he understood what children suffered living at streets on total poorness; so, he created a foundation for giving education and household to poor children; moreover, he worked very hard to create laws for the protection of children... (Fourth workshop, group 3, students' artifact.)

The excerpt above shows how this activity stimulated students' analysis of daily life problems which are part people's culture; likewise, one of the purposes of novels is to show people's lifestyle and culture from different perspectives. "Novels help students master the skills that will enable them to acquire information, process this knowledge, identify problems, formulate alternatives, and arrive at meaningful, thoughtful, effective decisions and solutions". Helton, Asamani and Thomas (as cited in Hişmanoğlu 2005, p. 64). In addition, Tsai (2012) regarded that novels have been considered one of the most complete genders to be included in the curriculum for teaching a foreign language; thus, when students were asked to create their own ending to the novel (Oliver Twist), they were encouraged to analyze, criticize, evidence problems and propose possible solutions from their own view point.

Finally, according to the previous analysis and the evidences, 
the abridged version of novels as an academic support motivated students' enrichment of knowledge and cultural aspects, it aroused students' interest for foreign cultures like the British and the European, places where the novels took place; the historical events as well as the traditions of people increased students' interest in working with this kind of material.

\section{Conclusions}

The inclusion of the abridged version of some novels in the English classes permitted researchers to approach students about literature issues that are important to enhance them improve their language use; additionally, students worked with some classic works of literature which guaranteed a good plot and the characters' performance; furthermore, students acquired new vocabulary, expressions, and pronunciation, all essential elements in language communication.

The workshops based on the different novels demanded students total involvement in the activities because at the end of each one, they had to show two products: the students' written paper and the oral reports; thus, students were led to use the language in order to share their summaries, descriptions of characters and events, as well as build their own texts; according to these processes, the results evidence that students gained a lot of practice and improvement basically in writing and speaking as part of their academic growth.

Moreover, the results of this research showed some other relevant benefits for students in terms of knowledge acquisition and cultural enrichment; hence, during the development of the different workshops, the novels allowed students to be immersed in people's development, customs, history, traditions and other aspects that are the legacy of the man's evolutions and progress along time.

Finally, through the development of this study, students experienced some difficulties, especially at the beginning of the activities; they showed problems in understanding the pronunciation of some words and expressions. While speaking, they also presented a lack of fluency and vocabulary. The progress of activities demonstrated that students got self-confidence to understand the material and also express their ideas about it. 


\section{References}

Abawi, K. (2013). Data collection instruments (Questionnaire \& Interview). Geneva Workshop. Retrieved from: http://www. gfmer.ch/SRH-Course-2012/Geneva- Workshop/pdf/Datacollection-instruments-Abawi-2013.pdf

Akhter, T. (2007). Giving feedback and correcting errors in ESL classroom. Department of English and Humanities. Dhaka, Bangladesh, BRAC University. Retrieved from: http://d space. bracu.ac.bd/xmlui/bitstream/handle/10361/128/ID\%2003203012. pdf?s sequence $=3 \&$ is Allowed $=\mathrm{y}$

Alba, F. (2015). Collaborative actions research. Education Scotland. Retrieved from: https://education.gov.scot/improvement/ Documents/sacfi12b-CAR-overview.pdf

Beach, R., Appleman, D., Hynds, S., \& Wildhelm, J. (2006). Teaching literature to adolescents. Lawrence Erlbaum Associates, Publishers. Mahwah, New Jersey. Retrieved from: https:// books.google.com.co/books?id=cWmAAAAAQBAJ\&pg=PT138\& $\underline{\operatorname{lp} \mid \mathrm{g}=\mathrm{PT} 1}$

Berardo, S. (2006). The use of authentic materials in the teaching of reading. The reading matrix. $6(2), 60-69$. Retrieved from: http://www.readingmatrix.com/articles/berardo/article.pdf

Buck, G. (2001). Assessing Listening. US: Cambridge University Press. Retrieved from: file:///c:/users/usuario/downloads/assessinglistening-hardback frontmatter\%20(5).pdf

Carvajal, N., \& Roberto, E. (2014). Collaborative work as an alternative for writing research articles. Profile. Issues in Teachers' Professional Development, 16 (1), 119-136.

Charmaz, K. (2006). Constructing grounded theory. A practical guide through qualitative analysis. London: Sage Publications. Retrieved from: http://www.sxf.uevora.pt/wpcontent/uploads/2013/03/Charmaz 2006.pdf

Chen, M. L. (2014). Teaching English as a foreign language through literature. Theory and practice in language studies. 4 (2), 232-236.

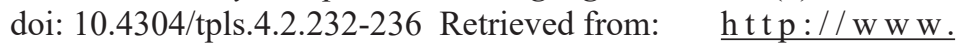
academypublication.com/issues/past/tpls/vol04/02/02.pdf

Cornillon, C. (2016). Book analysis, Frankenstein by Mary Shelley. A Reflection of the origin of the Evil. Retrieved from: https://books. google.com.co/books?id=mt6kCwAAQBAJ\&pg $=$ PP4\&lpg=PP4\& $\underline{\mathrm{dq}}=$ critique + to + the + novel + "Frankenstein $2 \&$ source 
Council of Europe, (2001). Common European Framework of Reference for Languages: Learning teaching assessment. Cambridge: Cambridge University Press.

Department of Education and Communities (2015). Strong start, great teachers - phase 3. types of feedback. Education and communities. NSW Government. Retrieved from: http://www.ssgt.nsw.edu.au/ documents/1types_feedback.pdf

Elftorp, F. (2007). How to improve students' writing and speaking skills? Sweden: Högskoland för Lärande Och Kommunikation (HLK). Retrieved from:http://hj.diva-portal.org/smash/get/ diva2:3635/FULLTEXT01.pdf

Giuria, L. (2015). Teaching literate in the ESL Classroom. A qualitative study on teachers' views of literature in an upper secondary school environment in Southern Sweden. Kristiansand University Sweden, Lund University. Retrieved from: http://lup.lub.lu.se/luur/download ? func $=$ downloadFile \&recordOId $=8596984 \&$ fileOI $\mathrm{d}=8596985$

Glaser, B., \& Strauss, A. (2006). The discovery of grounded theory. Strategies for qualitative research. New Brunswick (U.S.A.) and London (U.K.). Retrieved from: http://www.sxf.uevora.pt/wpcontent/uploads/2013/03/Glaser_1967.pdf

Hattie, J., \& Timperley, H. (2007). The power of feedback. Review of educational research. University of Auckland. 77(1), 81-112. Retrieved from: http://www.columbia.edu/ mvp19/ETF/Feedback. pdf

Hişmanoğlu, M. (2005). Teaching English through literature. Journal of languages and linguistic studies. 1(1), retrieved from: http://www. jlls.org/index.php/jlls/article/viewFile/6/7

Iida, M., Shout, P. Laurenceau, J. \& Bolger, N. (2012). APA Handbook of Research in Psychology: Foundations, Planning, Measures, and Psychometrics. Chapter 15, Using Diary Methods in Psychological Research. American Psychological Association. Retrieved from: http://www.columbia.edu/ nb2229/docs/Iida, \%20Shrout, $\% 20$ Laurenceau $\% 20 \& \% 2$

Koutsompou, V. (2015). The use of literature in the language classroom: methods and aims. International journal of information and education technology, 5(1), 74-79 Retrieved from: http://www.ijiet. org/papers/479-H10011.pdf 
McGreal, T., Broderick, E., \& Jones, J. (1984). Artifact collection. Association for supervision and curriculum development. Retrieved from: file:///C:/Users/Docente/Downloads/instruments.pdf

Phat, C. H. (2013). The Implementation of Literature in Teaching Speaking for Advanced Students. 3ed International Conference on Foreign Language Learning and Teaching. 1(2), p. 671-688. Viet Nam: Ho Chi Minh University of Education. Retrieved from: http://litu.tu.ac.th/2012/index.php/fllt-conferences/521-fllt-2013 conference-proceedings

Renukadevi, D. (2014). The role of listening in language acquisition; the challenge \& strategies in teaching listening. International journal of education and information studies. 4(1), 59-63. Research in Indian Publications. Retrieved from: https://www.ripublication. com/ijeisv1n1/ijeisv4n1_13.pdf

Ritlyavá, A. (2014). Creative use of literature in language teaching. Tvorivost'v škole - škola tvorivosti 2. ONLINE KONFERENCIA 29. - 30. 10. Retrieved from: file:///C:/Users/USUARIO/Downloads/ Ritlyova\%20 (1).pdf

Riwes, J. (2010). The role of literature and culture in English language teaching. Lingüistica aplicada. $\mathrm{N}^{\circ}$ 7. Universidad Autónoma Metropolitana. México. Retrieved from: http://relinguistica.azc. uam.mx/no007/no07 art09.pdf

Su, T., \& Tian, J. (2016). Research on corrective feedback in ESL/EFL Classroom. Theory and practice in language studies. 6(2), 439-444. DOI http://dx.doi.org/10.17507/tpls.0602.29

Tamo, D. (2009). The sue of authentic materials in classroom. Article 9 in LCPJ. 2(1) 74-78. Retrieved from: http://www.lcpj.pro/ skedaret/1277547685- $74 \_$pdfsam_LCPJ,\%20Per\%20shtyp.pdf

Tehan, P., Yuksel, D., \& Inan, B. (2015). The place of literature in an English language teaching program: what do students think about it. The reading matrix: An International online journal, 15 (2), 65-52. Retrieved from: http://www.readingmatrix.com/files/13-z5e1n026. pdf

Tsai, C. (2012). Students' perceptions of using novels as main material in the EFL reading course. English Language Teaching. Canadian Center of Science and Education, 5 (8), 103 - 112. Retrieved from: http://files.eric.ed.gov/fulltext/EJ1079768.pdf 
Vasu, K., Hui Lin, C., \& Nimehchisalem, V. (2016). Malaysian Tertiary Level ESL Students' Perceptions toward Teacher Feedback, P e e r Feedback and Self- assessment in their Writing. International journal of applied linguistics \& English literature. Australian International Academic Centre, Australia. 5(5) p. 58-170. Retrieved from: https://www.researchgate.net/profile/Vahid_Nimehchisalem/ publication/306148529Yeasmin, S. \& Rahman, K. (2012). Triangulation research method as the tool of social science research. Bup Journal.1(1), 154 - 163. Retrieved from: file:///C:/Users/ USUARIO/Downloads/TRIANGULATION.pdf

Yeo, R. (1986). Using abridged literature texts in second 1-3 can it be justified? Teaching and Learning. Institute of Education. Singapore. 7(1) 18-26. Retrieved from: https://repository.nie.edu.sg/ bitstream/10497/1925/1/TL-7-1-18.pdf 


\section{Authors}

*Gladis Leonor Arias Rodríguez holds a M.A. in Language Teaching from Universidad Pedagógica y Tecnológica de Colombia (UPTC) and M.A. in Pedagogy at Universidad Santo Tomas (USTA). She has experience in teaching English from primary to higher education. Her latest investigations have been in literacy, literature, curriculum, strategies for teaching general and ESP English, and stereotypes. She is currently editor of the Shimmering Words E-magazine, full time teacher and researcher at USTA in the "Expedicionarios Humanistas" group.

Eliana Edith Roberto Flórez holds a MA in Language Teaching from Universidad Pedagógica y Tecnológica de Colombia. Currently, she is a full time teacher at Universidad Santo Tomás in Tunja. She has supported the teaching process of English since 2005. Besides, she is recognized as a Junior researcher by Colciencias, she has been working in different areas of study and belong to "Expedicionarios Humanistas" research group categorized in B by Colciencias, and she is co-editor of the Shimmering Words E-magazine. Her goal is to help students' learning process of English according to their academic needs. 